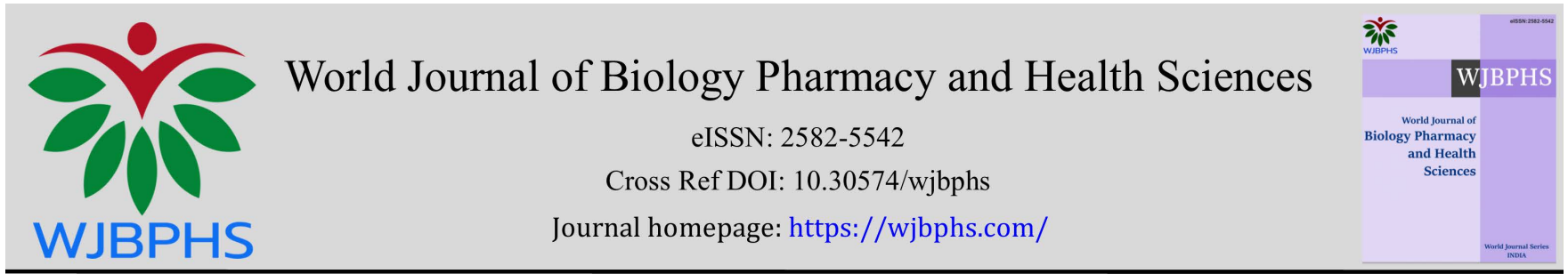

(RESEARCH ARTiCLE)

\title{
Antibacterial activity of lactobacillus species isolated from raw goat milk against Staphylococcus aureus
}

\author{
Emeka Okechukwu ${ }^{1,}{ }^{*}$, Joy Nkeiruka Dike-Ndudim ${ }^{1}$, Chizaram Winners Ndubueze ${ }^{1}$ and Charlotte Chinwendu \\ Iwuji-Aguzie ${ }^{2}$
}

\section{${ }^{1}$ Department of Medical Laboratory Science, Faculty of Health Sciences, Imo State University, Owerri, Nigeria. \\ ${ }^{2}$ Department of Medical Laboratory Science, Federal Medical Centre, Owerri, Nigeria.}

World Journal of Biology Pharmacy and Health Sciences, 2021, 06(02), 065-072

Publication history: Received on 12 April 2021; revised on 14 May 2021; accepted on 17 May 2021

Article DOI: https://doi.org/10.30574/wjbphs.2021.6.2.0055

\begin{abstract}
Lactobacillus spp. are known to have many health benefits and are mostly used as probiotics. They can cause inhibition of certain micro-organisms by the reduction of $\mathrm{pH}$ due to production of lactic acid, hydrogen peroxide and antimicrobial compounds such as bacteriocins. The antibacterial; activity of Lactobacillus spp. Against Staphylococcus aureus was evaluated using agar well diffusion method. Three raw goat milk samples were pooled together, serially diluted, cultured on MRS (De Man, Rogosa, Sharpe) Agar, and purified. Four Lactobacillus species were isolated and identified by biochemical tests as L. lactis, L. plantarum, L. Casei and L. Fermentum. Antibacterial activity of the four isolates against the test organism, Staphylococcus aureus, was determined by agar well diffusion method following the extraction of crude and precipitated bacteriocin from the isolates. All the isolates produced antagonistic effects against the test organism with maximum zones of growth inhibition produced by precipitated bacteriocin [14.0mm (L. casei) to $16.0 \mathrm{~mm}$ (L. lactis)] whereas minimum zones of growth inhibition was produced by crude bacteriocin $[8.0 \mathrm{~mm}$ (L. casei) to $11.0 \mathrm{~mm}$ (L. lactis)]. The results obtained confirmed that the four Lactobacilli isolated have growth inhibitory effects against Staphylococcus aureus and can therefore serve as important probiotic organism. It also goes further to show the importance of Lactobacillus bacteriocins as food bio-preservatives. This therefore justifies an in-depth investigation for the identification and application of these organisms in generating alternative antibacterial therapies for human and animal diseases to counter the problem of bacteria antibiotic resistance in recent years.
\end{abstract}

Keywords: Lactobacillus; Staphylococcus; Antibacterial; Resistance; Bacteriocin; Medicinal

\section{Introduction}

Lactic Acid Bacteria (LAB) constitutes a group of genus that has the following common features: cocci, rods and a basic composition of DNA below $50 \mathrm{~mol} \% \mathrm{G}+\mathrm{C}$. They are typically Gram positive, mesophilic, can grow within $5^{\circ} \mathrm{C}$ to $45^{\circ} \mathrm{C}$ under aerobic, anaerobic or microaerobic conditions and are asporogenous. In addition, they are oxidase and catalase negative, cannot reduce nitrate to nitrite and are incapable of producing indole or hydrogen sulphide. This group consists of numerous genera: Lactobacillus, Lactococcus, Leuconostoc, Carnobacterium, Streptococcus, Enterococcus, Aerococcus, Bifidobacterium and Pediococcus [10, 6, and 14].

Lactic Acid Bacteria (LAB) are found in a plethora of niches, including plant material, fermented dairy, vegetable and meat products, and sour dough breads. Lactic acid bacteria have been long established as the normal flora in fermented food [12].

\footnotetext{
* Corresponding author: Emeka Okechukwu

Department of Medical Laboratory Science, Faculty of Health Sciences, Imo State University, Owerri, Nigeria. 
In recent years LAB have been playing important role in the food and feed fermentation and preservation either as the natural microflora or as starter culture added under controlled conditions. Foods fermented by LAB are rendered more adapted for longer preservation and have improved textures, flavours and tastes [15]. This is due to the fact that they have been recognized as GRAS (Generally Recognized as Safe) microorganisms. S. thermophilus is a lactic acid bacterium of major importance in food industry e.g. the manufacture of yogurt. The preservative effect exerted by LAB is mainly due to the production of organic acids (such as lactic acid) [11].

Lactic acid producing bacteria are known to have other various beneficial functions such as anti-tumour activity, reduction of serum cholesterol, alleviation of lactose intolerance, stimulation of the immune system, enhancement of resistance against certain bacteria (antimicrobial action) and prevention of diarrhea's [34, 2]. Based on these functions, different kinds of LAB have been developed as probiotics, and the market volume of probiotics has rapidly increased $[20,8]$.

The antimicrobial effect of LAB has been appreciated by man for more than 1000 years ago and has enabled him to extend the shelf life of many foods through fermentation processes since it can inhibit the growth of such microorganisms including spoilage and pathogenic bacteria $[5,29]$.

The antibacterial action of lactic acid is largely, but not totally, assigned to its ability in the non-dissociated form to penetrate the cytoplasmic membrane of organisms, resulting in reduced intracellular $\mathrm{pH}$ and disruption of the Trans membrane proton motive force [33].

This effect may also have resulted from the action of organic acids, hydrogen peroxide, diacetyl and/or a compound(s) called bacteriocin(s) [30, 36, and 19]. The inhibition of pathogenic bacteria such as Staphylococcus aureus by lactic microflora was announced by Heikkila and Saris [21].

Bacteriocins are proteinaceous compounds that mainly inhibit closely related species [22]. Some bacteriocins have been shown to possess the ability to inhibit the actions of unrelated genera such as Clostridia, Listeria, enter pathogenic bacteria and gram-negative bacteria.

An arid variety of $\mathrm{LAB}$, that produce antimicrobial substance such as hydrogen peroxide, $\mathrm{CO}_{2}$, diacetyl, acetaldehyde, $\mathrm{D}$ isomers of amino acids, reuterin and bacteriocins have already been isolated from many fermented products. This includes naturally fermented sausages [5] fermented milk and dairy products and silage which is stored fermented vegetable product [27].

The discovery of bacteriocins gave a new way for food development in better hygienic quality [7]. In recent years, there have been many reports on bacteriocins that are produced by lactic acid bacteria. However, most reports deal with bacteriocins that are produced by various Lactococci, Pediococci, Leuconostoc, Enterococci and Lactobacilli [26]. The search for new strains of lactic acid bacteria that produce antimicrobial substances is a universal objective for the creation of new cultures starter with a high biosafety for fermented food.

In order to avoid the side effect of chemical preservatives these last years, the bacteriocins or strains of lactic acid bacteria for applications as bio-preservative caused many research tasks [3]. Several lactic acid bacteria bacteriocins offer potential applications in food preservation and the use of bacteriocins in the food industry can help reduce the addition of chemical preservatives as well as the intensity of heat treatments, resulting in foods which are more naturally preserved and richer in organoleptic and nutritional properties [18].

Food contamination by Staphylococcus aureus is a major problem to consumer's health in Nigeria, especially during the summer period. The pathogens come in contact with the food during both preparation and preservation. Improper food preparation includes; cooking with water polluted by faecal materials, improperly washed vegetables, fruits and especially raw meat and fish with blood. Some of the pathogens die, while cooking, whereas some persist and cause diseases in the enteric and other parts of the body. Moreover, cooking for a short time also lets the pathogens to grow and thrive in food products. Foods in restaurants and particularly food from street side shops cause the most cases of food borne diseases [32].

When it comes to the spread of pathogens by ill preservation, it involves storing the food at wrong temperature, storing both raw and cooked food together, improper pasteurization of milk, not storing food in proper temperature and etc. In fact, dairy products and meat products are the most common sources for spreading diseases. 
In recent years also, bacterial antibiotic resistance has been considered a problem due to the extensive use of classical antibiotics in treatment of human and animal diseases [38, 24, and 35]. As a consequence, multiple resistant strains have appeared and have spread causing difficulties and the use of antibiotics as growth promoters has been restricted. Therefore, the continued development of new classes of anti-microbial agents has become of increasing importance to medicine $[23,17]$. Application of some bacterial peptides as anti-microbial substances can be one plausible alternative for abusive use of antibiotics in food and feed products.

Lactic acid produced by lactic acid starter culture bacteria functions as a natural antimicrobial component, having a generally recognized as safe status. Lactic acid is able to inhibit the growth of many types of food spoilage bacteria, including gram-negative species of the families Enterobacteriaceae and Pseudomonadaceae [13]. In this study Lactic acid bacteria (Lactobacillus) were isolated from raw goat milk and screened for antimicrobial activity against Staphylococcus aureus. This study was aimed at screening the antimicrobial activities of Lactobacillus isolated from raw goat milk against Staphlococcus aureus.

\section{Material and methods}

\subsection{Sample Collection}

A total $30 \mathrm{~mL}$ of raw, fresh goat milk sample was collected in sterile container from three different goats of different breeds. Ten (10) mL was collected from each and the samples were transported immediately to the laboratory in ice packs. In the laboratory, the three raw goat milk samples were bulked together prior to isolation.

\subsection{Microbial Isolation}

From the bulked milk samples, $1 \mathrm{~mL}$ was collected using sterile pipette and diluted in $9 \mathrm{~mL}$ of sterile distilled water to make an initial tenfold dilution $\left(10^{-1}\right)$. The solution was diluted serially in distilled water up to the $3^{\text {rd }}$ fold and $1 \mathrm{~mL}$ of each sample (dilution) was cultured on sterile MRS Agar plates in duplicates by pour-plate method. The preparation was incubated in microaerophilic condition at $37^{\circ} \mathrm{C}$ for 48 hours. Viable colonies were calculated and expressed as $\log _{10} \mathrm{CFU} / \mathrm{mL}$. The Total Viable counts were determined using the formula below;

$$
\operatorname{TVC}(\mathrm{CFU} / \mathrm{mL})=\frac{1}{V} \times N \times \times D
$$

Where, $\mathrm{V}=$ Volume of inoculums, $\mathrm{N}=$ Number of colonies counted and $\mathrm{D}=$ Dilution factor

Pure colonies were obtained by sub-culturing isolates on new MRS Agar for 24 hours and in slant agars. The pure isolates were subjected to identification as per the Bergey's Manual of Determinative bacteriology using relevant microscopic and biochemical tests. The morphological characters of the isolates like colour, shape, margin and surface and cell morphology such as shape, arrangement, Gram and spore staining reaction, as well as motility were studied and reported.

\subsection{Identifications}

Furthermore, biochemical tests were used for the identification of bacterial isolates and the results were also recorded.

\subsection{Extraction of Bacteriocin}

After identification, cultures from each isolate were selected and inoculated into MRS broth and incubated at $37^{\circ} \mathrm{C}$ for 24-48 hours under microaerophilic condition. After fermentation, broth was centrifuged at $12000 \mathrm{rpm}$ for $15 \mathrm{~min}$. and the cell free supernatant (CFS) was collected. The pH of CFS was adjusted to 7.0 (neutral) with $2 \mathrm{~N} \mathrm{NaOH}$ and labelled as crude bacteriocin preparation [37].

Since some bacteria secrete bacteriocins in minute amounts, there is need for purification of the cell free supernatant (crude bacteriocin) by the method of Lowy, [25]. For this, ammonium sulphate was added to the CFS till 70\% saturation and then the solutions were incubated at $4^{\circ} \mathrm{C}$ for 30 minutes with mild shaking. After precipitation, the broth was centrifuged at 15,000 rpm for 15 minutes and the supernatants were decanted until only $1 \mathrm{~mL}$ of CFS remained in the test tube. Precipitate was collected and stored in 0.2M Sodium phosphate buffer ( $\mathrm{pH}$ 6.9) and preparation [28]. 


\subsection{Antibacterial activity testing}

With the help of agar well diffusion method of Park et al., [31] antimicrobial activity of both the crude and precipitated bacteriocin preparations were checked for to confirm the presence of antimicrobial substances in it.

The antibacterial activity of the isolates of Lactobacillus against the test organism, Staphylococcus aureus, was determined by the agar well diffusion method [31].

Prior to the antimicrobial activity testing, Muller-Hilton (MH) agar plates were prepared according to manufacturer's instruction and the test organism was inoculated and incubated overnight in nutrient agar (NA). After 24 hours, discrete bacterial colonies from the NA plates were picked and transferred to sterile saline solution. Using a sterilized cotton swab, Muller-Hilton (MH) agar plates were spread with the test organism's saline suspension and within 15 minutes, wells of $5 \mathrm{~mm}$ were cut using a sterilized cork borer.

\subsection{Statistical Analysis}

Data from this study were entered and analyzed using Statistical Package for Social Sciences (SPSS) version 21 and Microsoft Excel.

\section{Results}

Table 1 shows the viable bacteria count from each of the samples from $10^{-1}$ to $10^{-3}$ dilutions after 48 hours incubation. From the table, the bacterial load of the bulked milk sample decreases with increased dilution of the sample. The mean viable count was obtained mathematically;

$$
\text { mean viable count }=\frac{\text { Plate } 1+\text { Plate } 2}{2}
$$

Table 1 Viable bacterial count from each of the samples from $10^{-1}$ to $10^{-3}$ dilutions after 48 hours incubation

\begin{tabular}{|c|c|c|c|c|c|}
\hline \multirow{2}{*}{ Dilution factor } & \multicolumn{2}{|c|}{ Viable count } & \multirow{2}{*}{ Mean Viable Count } & CFU/mL & \multirow{2}{*}{$\log _{\mathbf{1 0}} \mathbf{C F U} / \mathbf{m L}$} \\
\cline { 2 - 6 } & Plate 1 & Plate 2 & & $3.0 \times 10^{2}$ & 2.43 \\
\hline $10^{-1}$ & 32 & 28 & 30 & $2.35 \times 10^{3}$ & 3.37 \\
\hline $10^{-2}$ & 23 & 24 & 23.5 & $1.7 \times 10^{4}$ & 4.23 \\
\hline $10^{-3}$ & 16 & 18 & 17 & \\
\hline
\end{tabular}

Table 2 shows the colonial morphologies and microscopic appearances of the bacterial isolates. All isolates showed positive Gram stain reaction, but spore stain negative. Isolate 2, 3 and 4 appeared rod shaped, whereas isolate 1 was coccobacilli in form. However, all isolates were non-motile.

Table 2 Colonial and cellular morphologies of pure bacterial isolates

\begin{tabular}{|l|l|l|l|l|l|}
\hline $\begin{array}{l}\text { Isolate } \\
\text { Number }\end{array}$ & Colony Morphology & $\begin{array}{l}\text { Gram } \\
\text { Reaction }\end{array}$ & Shape & Motility & Spore \\
\hline 1 & circular cream-white smooth colonies & + & Cocobacilli & - & - \\
\hline 2 & $\begin{array}{l}\text { White slightly raised smooth round } \\
\text { colonies }\end{array}$ & + & Rod & - & - \\
\hline 3 & White circular smoothraised colonies & + & Rod & - & - \\
\hline 4 & Small cream-white smooth round colonies & + & Rod & - & - \\
\hline
\end{tabular}

${ }^{*}(-)=$ Negative; ${ }^{*}(+)=$ Positive 
Table 3 shows relevant biochemical tests performed on the bacterial isolates. The isolates were identified as $L . l a c t i s, L$. plantarum, L. Casei and L. Fermentum by their respective biochemical test reactions.

Table 3 Biochemical identification of the bacterial isolates

\begin{tabular}{|c|c|c|c|c|c|c|c|c|c|c|c|c|c|}
\hline \multirow[t]{2}{*}{ Isolate Number } & \multicolumn{4}{|c|}{$\begin{array}{l}\text { Carbohydrate } \\
\text { utilization }\end{array}$} & \multirow{2}{*}{ 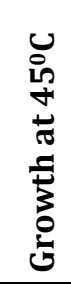 } & \multirow[b]{2}{*}{$\frac{0}{0}$} & \multirow[b]{2}{*}{ 菢 } & \multirow[b]{2}{*}{ 兽 } & \multirow[b]{2}{*}{ 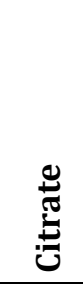 } & \multirow[b]{2}{*}{ 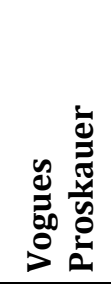 } & \multirow[b]{2}{*}{ 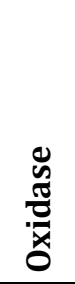 } & \multirow[b]{2}{*}{ 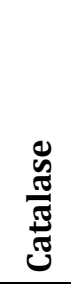 } & \multirow[t]{2}{*}{ Isolate Identity } \\
\hline & 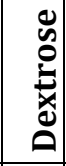 & 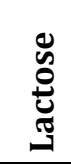 & 巳̊ & 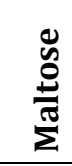 & & & & & & & & & \\
\hline Isolate 1 & A & A & A & A & + & - & - & - & - & - & - & - & Lactobacillus lactis \\
\hline Isolate 2 & A & A & A & NA & - & - & - & - & - & - & - & - & $\begin{array}{l}\text { Lactobacillus } \\
\text { plantarum }\end{array}$ \\
\hline Isolate 3 & A & A & A & A & + & - & - & - & - & - & - & - & Lactobacills casei \\
\hline Isolate 4 & A & A & A & A & - & - & - & - & - & - & - & - & $\begin{array}{l}\text { Lactobacillus } \\
\text { fermentum }\end{array}$ \\
\hline
\end{tabular}

Table 4 shows the results of the antimicrobial susceptibility testing for bacterial isolates measured in mm. However, it seems that the antimicrobial activity of the isolates have no direct correlation with extent of antimicrobial activity exhibited as little or no difference is observed in the zones of inhibition for both the crude and precipitated bacteriocin.

Table 4 Antimicrobial susceptibility testing for bacterial isolates

\begin{tabular}{|c|c|c|c|c|}
\hline \multirow[t]{2}{*}{ Organisms } & \multicolumn{2}{|c|}{ Zone of Inhibition (mm) } & \multirow{2}{*}{$\begin{array}{l}\text { Mean zone } \\
\text { of inhibition } \\
(\mathrm{mm})\end{array}$} & \multirow{2}{*}{$\begin{array}{l}\text { Mean } \pm \text { SD zone } \\
\text { of inhibition }\end{array}$} \\
\hline & $\begin{array}{l}\text { Crude } \\
\text { extract }\end{array}$ & $\begin{array}{l}\text { Precipitated } \\
\text { (Purified) }\end{array}$ & & \\
\hline L. lactis & 10.0 & 16.0 & 13.0 & $13.0 \pm 4.24$ \\
\hline L. plantarum & 11.0 & 15.0 & 13.0 & $13.0 \pm 2.83$ \\
\hline L. Casei & 8.0 & 14.0 & 11.0 & $11.0 \pm 4.95$ \\
\hline L. Fermentum & 11.0 & 15.0 & 13.0 & $13.0 \pm 2.12$ \\
\hline
\end{tabular}

\section{Discussion}

Lactobacillus spp. are known to have many health benefits and are mostly used as probiotics. They can cause inhibition of certain micro-organisms by the reduction of $\mathrm{pH}$ due to lactic acid production, hydrogen peroxide production and production of antimicrobial compounds such as bacteriocin.

In recent years, bacterial antibiotic resistance has been considered a problem due to the extensive use of classical antibiotics in treatment of human and animal diseases [35] and hence the continued development of new classes of antimicrobial agents has become of increasing importance to medicine $[17,23]$.

In this study, aimed at assessing the antibacterial potency of Lactobacilli isolates obtained from raw goat milk samples was embarked on and four Lactobacillus species identified were tested for their antibacterial activity against Staphylococcus aureus.

These isolates have also been reported as the most predominant species of Lactobacillus in raw goat milk in a similar study (Characterization of Lactobacillus from Algerian Goat's milk based on phenotypic, 16S rDNA Sequencing and their 
technological properties) conducted by Ahmed et al. [1]. The findings of this study therefore agree with Ahmed et al., report but for the substitution of L. fermentum with L. paracasei.

All the isolates in this study produced antagonistic effects against the test organism Staphylococcus aureus. These results support the reports of Arokiyamary et al. [4] who isolated the bacteriocin producing Lactobacillus species from traditional milk products and reported its antimicrobial activity against common pathogens.

In this study, it was also observed that the maximum zones of growth inhibition against test organism was produced by precipitated (purified) bacteriocin with diameter ranging from $14.0 \mathrm{~mm}$ (L. casei) to $16.0 \mathrm{~mm}$ (L.lactis), whereas minimum zones of growth inhibition was produced by crude bacteriocin with diameter ranging from $8.0 \mathrm{~mm}(\mathrm{~L}$. casei) to $11.0 \mathrm{~mm}$ (L. lactis), which corobate the reports of Enan et al. [16]. The difference in antibacterial activity of the purified (precipitated) and crude extracts on the isolates, which showed inhibition zones between 0.5 to $13.00 \mathrm{~mm}$ in diameter by crude bacteriocin and zones of growth inhibition between 12 to $32 \mathrm{~mm}$ for partially purified (precipitated) bacteriocin is traceable to the purity level of the precipitated bacteriocin used compared to the crude bacteriocin.

The results of present study showed that the four different Lactobacillus spp. isolated were important probiotic organisms which have growth inhibitory effects against Staphylococcus aureus.

In this study also, it was discovered that all isolates have antibacterial effects against Staphylococcus aureus which is a Gram-positive bacterium. This is in line with the report of Savadogo et al. [35] who confirmed that gram-positive bacteria are more sensitive than gram-negative. Jamalifar et al., researched on screening of Lactobacillus strains against Pseudomonas aeruginosa and they found that some Lactobacilli such as Lactobacillus acidophilus showed significant inhibitory activity against the multidrug resistant clinical isolates of Pseudomonas aeruginosa.

\section{Conclusion}

The results obtained in this study confirmed that Lactobacilli possess growth inhibitory effects against Staphylococcus aureus and can therefore serve as important probiotic organism justifying a more in depth investigation for their identification and application as food bio preservatives. It also showed the health importance of lactobacillus which is hinged on the unique property they possess and which can be harnessed in generating alternative antibacterial therapies for human and animal diseases to counter the problem of bacteria antibiotic resistance.

However, further work is needed to ascertain whether there is a relationship between the species of Lactobacillus isolated from raw goat milk samples and their antibacterial potential. Also more investigations to fully understand the molecular mechanisms, structure-function relationships and mechanisms of action of bacteriocins for exploration of applications should be performed.

\section{Compliance with ethical standards}

\section{Acknowledgments}

We want to acknowledge the staff and students of the Department of Medical Laboratory Science as well as our family members who supported us throughout the period of the research.

\section{Disclosure of conflict of interest}

There is no conflict of interest.

\section{References}

[1] Ahmed M, Manuel Z, Mabrouk K, Gasper P. Characterization of Lactobacillus from Algerian Goat's Milk Based on Phenotypic, 16S Rdna Sequencing and their Technological properties. Brazil Journal of Microbiology. 2011; 42(1): 158-171.

[2] Aimutis WR. Microflora of the intestine / biology of Lactobacillus acidophilus. In Robinson RK, Batt CA, Patel PD, eds. Encyclopedia of Food Microbiology. 2nd ed. London: Academic Press. 2009; 1361-65.

[3] Alvarez-Martin P, Florez AB, Barranco H, Mayo B. Interaction between dairy yeasts and lactic acid Bacteria strains during milk fermentation. Food Control. 2008; 19: 62-70. 
[4] Arokiyamary A, Shivkumar PK. ntibacterial activity of bacteriocin producing Lactobacillus sp., isolated from traditional milk products. Current Botany. 2011; 2(3): 5-8.

[5] Aslim B, Onal D, Beyatli Y. Factors influencing auto aggregation and aggregation of Lactobacillus delbrueckii subsp. bulgaricus isolated from handmade yogurt. Journal of Food Protection. 2007; 70: 223-227.

[6] Axelsson L. Lactic Acid Bacteria, Classification and Physiology. In Salminen S, Von WA, Ouwehand A, eds. Lactic Acid Bacteria. 3rd ed. New York: Marcel Dekker. 2004; 14.

[7] Badis A, Guetarni D, Moussa-Boudjema B, Henni DE, Kihal M. Identification and technological properties of lactic acid bacteria isolated from raw goats milk of furnace Algerian races. Food Microbiology. 2004; 21(5): 579-588.

[8] Brashears MM, Jaroni D, Trimble J. Isolation, selection and characterization of lactic acid bacteria for a competitive exclusion product to reduce shedding of Escherichia coli 0157:H7 in cattle. Journal of Food Protection. 2003; 66: 355-363.

[9] Carr FJ, Chill D, Maida NR. The lactic acid bacteria: With literature Survey. Current Revolutions in Microbiology. 2002; 28(4): 281-370.

[10] Daeschel MA. Antimicrobial substances from lactic acid bacteria for use as food preservatives. Food Technology. 1989; 43: 164-167.

[11] Desmazeaud M, Cogan TM. Role of cultures in cheese ripening. In: Dairy Starter Cultures. Cogan TM, Joined JP. eds. New York: VCH Publishers, Inc. 2006; 207-231.

[12] Doores S. Organic acids. In Davidson PM, Branen AL. Eds. Antimicrobials in foods. New York: Marcel Dekker, Incorporated. 1983; 95-136.

[13] Doyle MP, Meng J. Bacteria in Food and Beverage Production. In Dworkin M, Falkow S, Rosenberg E, Schleifer KH, Stackebrandt E. Eds. The Prokaryotes. 3rd Edition. Springer. 2006; 59-63.

[14] El-Ghaish S, Ahmadova A, Hadji SI, El Mecherfi K, Bazukyan I, Choiset Y, Rabesona H, Sitohy M, Popov Y, Kuliev A, Mozzi F, Chobert J, Haertle T. Potential use of lactic acid bacteria for reduction of allergenicity and for longer conservation of fermented foods. Trends in Food Science and Technology. 2011; 22: 509-516.

[15] Enan G, Essawy AA. Antibacterial activity of Lactobacillus plantarum UGI isolated from dry sausage: Characterization, production and bactericidal action of Plantaricin UGI. International Journal of Microbiology. 1996; 30: 189-215.

[16] Fisher JF, Meroueh SO, Mobasher YS. Bacterial resistance to betalactam antibiotics: compelling opportunism, compelling opportunity. Chemical Revolution. 2005; 105: 395-424.

[17] Gálvez A, Abriouel H, López RL, Omar BN. Bacteriocin-Based Strategies for Food Biopreservation. International Journal of Food Microbiology. 2007; 12: 51-70.

[18] Gonzalez L, Sacristán N, Arenas R, José M, Fresno JM, Tornadijo E. Enzymatic activity of lactic acid bacteria (with antimicrobial properties) isolated from a traditional Spanish cheese. Food Microbiology. 2010; 27: 592-597.

[19] Hamilton-Miller JM. The role of probiotics in the treatment and prevention of Helicobacter pylori infection. International Journal of Antimicrobial Agents. 2003; 30: 175-176.

[20] Heikkila MP, Saris PEJ. Inhibition of Staphylococcus aureus by the commensal bacteria of human milk. Journal of Applied Microbiology. 2003; 95: 471-478.

[21] Klaenhammer TR. Genetics of Bacteriocins Produced by Lactic Acid Bacteria. Federation of European Microbiological Societies, Microbiology Reviews. 1993; 12: 43-56.

[22] Kumar A, Schweiser HP. Bacterial resistance to antibiotics: active efflux and reduced uptake. Advanced Drug Delivery Reviews. 2005; 57: 1486-1513.

[23] Lipsitch M, Bergstrom CT, Levin BR. The epidemiology of antibiotic resistance in hospitals: paradoxes and prescriptions. Proc. National Academy of Science, USA. 2000; 97: 1938-1943.

[24] Lowy FD. Staphylococcus aureus infections. New England Journal of Medicine. 1998; 339: 520-532.

[25] Mc Auliffe 0, Ross RP, Hill C. Lantibiotics structure, biosynthesis and mode of action. FEMS Microbiology Revolution. 2011; 25: 285-308.

[26] Morea M, Baruzzi F, Cocconcelli PS. Molecular and physiological characterization of dominant bacterial populations in traditional Mozzarella cheese processing. Journal of Applied Microbiology. 1999; 87: 574-582. 
[27] Navarro L, Zarazaga M, Saenz J, Ruiz-Larrea F, Torres C. Bacteriocin production by Lactic acid bacteria isolated from Rioja red wines. Journal of Applied Microbiology. 2000; 88: 44-51.

[28] Okereke HC, Achi OK, Ekwenye UN, Orji FA. Antimicrobial properties of probiotic bacteria from various sources. African Journal of Biotechnology. 2012; 11(39): 9416-9421.

[29] Oyetayo VO, Adetuyi FC, Akinyosoye FA. Safety and Protective effect of Lactobacillus acidophilus and Lactobacillus casei used as probiotic agent in vivo. African Journal of Biotechnology. 2003; 2: 448-452.

[30] Park JH, Seok SH, Cho SA, Baek MW, Lee HY, Kim DJ, Chung MJ, Kim SD, Hong UP. Antimicrobial effect of lactic acid producing bacteria culture condensate mixture (LCCM) against Salmonella enteritidis. International Journal of Food Microbiology. 2005; 101(1): 111-117.

[31] Rane S. Street Vended Food in Developing World: Hazard Analyses. Indian Journal of Microbiology. 2011; 33: 98 102.

[32] Ray B, Sandine WE. Acetic, propionic, and lactic acids of starter culture bacteria as biopreservatives. In Ray B, Daeschel M. Eds. Food preservatives of microbial origin CRC Press. 1992; 103-136.

[33] Reid G. Safe and efficacious probiotics: what are they? Trends in Microbiology. 2006; 14: 348-352.

[34] Roy PH. Dissemination of antibiotic resistance. Medical Science. 2008; 13: 927-933.

[35] Savadogo A, Ouattara Cheik AT, Bassole Imael HN, Alfred T. Antimicrobial activities of lactic acid bacteria strain from Burkina Faso fermented milk. Pakistan Journal of Nutrition. 2004; 3: 174-179.

[36] Vijai P, Marilinggappa J, Kadirvelu J. Isolation and Characterization of Bacteriocin producing lactic acid bacteria from South Indian special dosa (appam) Batter. Journal of culture collections. 2004; 4: 53-60.

[37] Yoneyama H, Katsumata R. Antibiotic Resistance in Bacteria and Its Future for Novel Antibiotic Development. Bioscience. Biotechnology. Biochemistry. 2006; 70: 1060-1075. 